\title{
Patterns and security technologies for co-extraction of coal and gas in deep mines without entry pillars
}

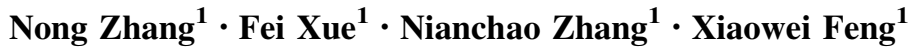

Received: 20 March 2015/Revised: 1 April 2015/Accepted: 3 April 2015/Published online: 9 May 2015

(C) The Author(s) 2015. This article is published with open access at Springerlink.com

\begin{abstract}
Retaining gob-side entryways and the stability of gas drainage boreholes are two essential techniques in the coextraction of coal and gas without entry pillars (CECGWEP). However, retained entryways located in deep coal mines are hard to maintain, especially for constructing boreholes in confined spaces, owing to major deformations. Consequently, it is difficult to drill boreholes and maintain their stability, which therefore cannot guarantee the effectiveness of gas drainage. This paper presents three measures for conducting CECGWEP in deep mines on the basis of effective space in retained entryways for gas drainage. They are combinations of retaining roadways and face-lagging inclined boreholes, retaining roadways and face-advancing inclined boreholes, and retaining roadways and high return airway inclined boreholes. Several essential techniques are suggested to improve the maintenance of retained entryways and the stabilization of boreholes. For the particular cases considered in this study, two field trials have verified the latter two measures from the results obtained from the faces 1111(1) and 11112(1) in the Zhuji Mine. The results indicate that these models can effectively solve the problems in deep mines. The maximum gas drainage flow for a single hole can reach $8.1 \mathrm{~m}^{3} / \mathrm{min}$ and the effective drainage distance can be extended up to $150 \mathrm{~m}$ or more.
\end{abstract}

Keywords Retaining gob-side entryways - Stability of borehole $\cdot$ Gas pressure relief $\cdot$ Co-extraction of coal and gas without the entry pillar

\section{Introduction}

As an associated product of coal production, gas is an innovative clean energy and high-class chemical material, although it may cause major life threatening disasters in collieries and increase the greenhouse effect in the atmosphere (Zhang et al. 2013; Xue et al. 2014). The gas can be scientifically used and serve as one of the most important consequential energy resources in the 21st-century (Yuan 2008; Xie et al. 2014). Appropriate gas drainage in collieries can guarantee safe production, and decrease the

Nong Zhang

zhangnong_cumt@163.com

1 School of Mines, Key Laboratory of Deep Coal Resource Mining, Ministry of Education, China University of Mining \& Technology, Xuzhou 221116, China emission of greenhouse gas (Bibler et al. 1998; Karacan et al. 2011; Keim et al. 2011; Xia et al. 2014; Zhou et al. 2014). The earliest gas drainage technique was applied in 1938, and two main approaches to drainage have been developed through the investigations of several generations (Yuan et al. 2013). They are known as surface and underground drainage. Multiple technical solutions for gas drainage have been developed based on related research and field trials. On account of different drainage situations, such as current coal seams, neighboring coal seams, and gob-areas, they can be divided into many categories. These include horizontal boreholes, intersection boreholes and grid-layout boreholes in current coal seams, boreholes through the roof or floor in neighboring coal seams, fracturing zone drainage, buried pipes drainage, and surface drainage aimed at gas in the gob area (Zheng et al. 2013; Pan et al. 2014). Research teams in China also developed deep-hole presplitting blasting, hydraulic cutting, hydraulic 
drilling or reaming, to increase the permeability of coal or rock strata. These techniques have been widely applied in coal mines more than $1000 \mathrm{~m}$ deep. Nonetheless, in view of the poor permeability of coal seams, complex geological conditions, high gas content, potential explosions of coal and gas, and limited coal production in China, problems involving large investments in hole drilling and specially designed drainage entries will arise if we continue using these traditional measures.

Co-extraction of coal and gas without any entry pillars (CECGWEP) has been developed for gas extraction using pressure relief theory, which is illustrated in Fig. 1. Based on the conditions of coal seams, a technically minable coal seam is chosen as the first to be mined. This seam is called "the preferential coal seam" which is used to release the high initial gas pressure ( $\mathrm{Li}$ et al. 2014; Yang et al. 2014). In CECGWEP, traditional gas drainage entries located in either the roof above or the floor below are replaced by gob-side retained entries in the preferential coal seam; a traditional U-type ventilation passageway is changed into a Y-type ventilation passageway. A series of potential problems, such as gas outbursts, coal mining problems, high temperatures controlling, relief of high underground pressure, and support of surrounding rock, are considered in the technology and it has already been widely applied by the Huainan Mining Group, Shanxi Coking Coal Group, Huaibei Mining Group, and Jincheng Anthracite Group.

However, although this technology has several merits, it is difficult to adopt in every coal mine, especially deep buried soft rock coal mines, where the entryway convergence is extremely severe (Zhang et al. 2012; Kong et al. 2014). It thus requires optimization on the basis of the complex geology. The purpose of this paper is to describe the implementation of CECGWEP in deep coal mines and

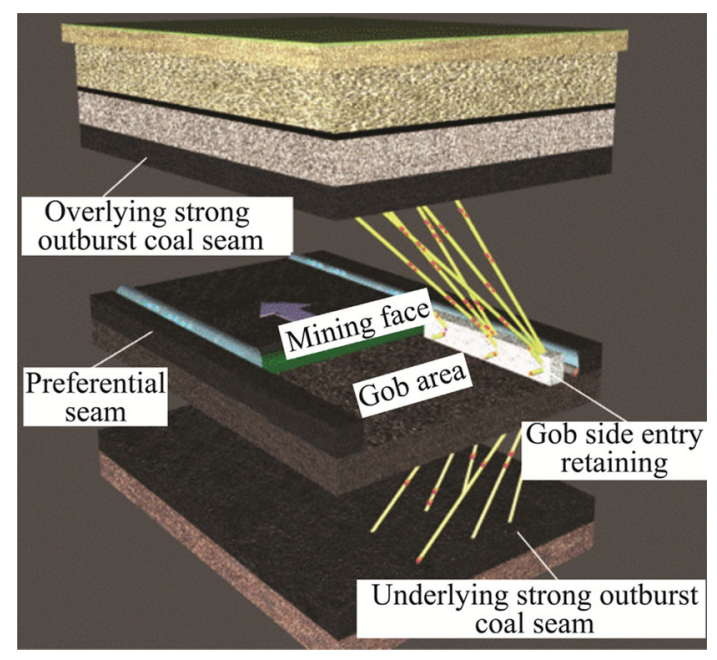

Fig. 1 Schematic diagram of CECGWEP present a systematic summary of the key techniques based on field trials in recent decades.

\section{Technical challenges of CECGWEP in deep mines}

\subsection{Large deformations in rock mass lead to difficulties in drilling drainage boreholes in retained entryways}

Gob-side entry retaining in deep coal mines is subject to high ground stress, high temperature, and severe mining pressure. The scope for breakage in rock masses is relatively large, and may cause a fracture line in the immediate roof which propagates into the coal seam. This will dramatically induce large subsidence and rotation moments in the roof, severe dilatation and buckling of coal sides, and uncontrollable floor heaving. These phenomena distinctly separate deep buried coal mines from shallow buried coal mines (Kang et al. 2010).

Figure 2 displays the relationship between the sectional area of the retained entryway and the correlated distance to the workface in the Zhuji and Panyidong Mines. It is apparent that the deformation of the surrounding rock in different faces shows different levels, which are directly related to their buried depth and the lithology of the roof and floor. All four original sectional areas are $12 \mathrm{~m}^{2}$. The face 1252(1) is relatively shallow compared with the others, the sectional areas at 20,40 and $60 \mathrm{~m}$ in front of the face are $11.8,10.9$ and $9.7 \mathrm{~m}^{2}$, respectively, and the convergence rate of the stabilized segment in the retained entryway is $35 \%$. However, it is totally different for the face 1111(1), where it is buried relatively deeper than the other three, and the lithology consists of soft rocks. Its sectional areas at 20,40 and $60 \mathrm{~m}$ in front of the face are $4.9,4.3$ and $4.2 \mathrm{~m}^{2}$, respectively, and the convergence rate of the stabilized segment in the retained entryway is $66 \%$, which is almost double that of face 1252(1).

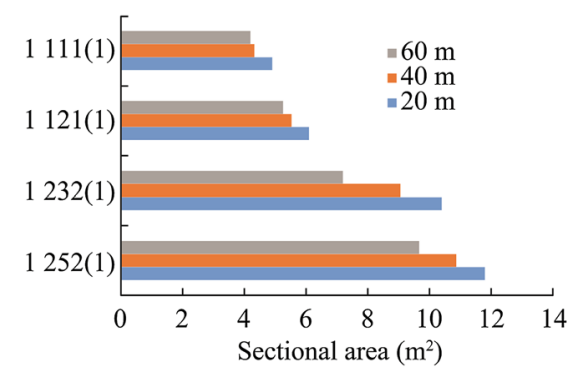

Fig. 2 Relationship between the sectional area of a retained entryway and the distance to the working face (All the original sectional areas were $12 \mathrm{~m}^{2}$ ) 
Additionally, to maintain total stability of the roof in the retained entryway, two or three rows of single hydraulic props are recommended to be suitably arranged and timber cribs are built along the backfilling wall to serve as auxiliary supports. It thus greatly restrains the space for drilling holes designed to drain gas.

\subsection{Frequently occurring cutting and blocking of drainage holes and low efficiency in drainage}

The drilled holes in an arrangement on the gob side are subjected to dramatic mining induced pressure because of the severe movement of strata in coal seam mining (Zhang et al. 2014). A frequent phenomenon is the cutting and blocking of drilling holes (Lu et al. 2014). A drainage pipe cannot be effectively guaranteed. This thus significantly restricts the high drainage rate of gas (Whittles et al. 2007). Field monitoring reveals that the average drainage rate of a single hole is less than $0.3 \mathrm{~m}^{3} / \mathrm{min}$. Hence, the drainage rate cannot be guaranteed. Concentration of gas around the working face always reaches the ultimate limit, which slows mining, and makes the co-excavation of coal and gas hard to implement.

\subsection{Requirements for hole-creating and safety are hard to implement using lagging drilling behind the face}

It has been established through field observations that the entryway rock from 20 to $60 \mathrm{~m}$ behind the workface is extremely fractured. Borehole drilling into this range is extremely difficult because the drill stem jams frequently, or boreholes collapse. Hence, the requirement for a standard borehole is hard to fulfil. At the same time, a large amount of gas can penetrate into the gob area through mining induced fissures. Gas escapes very easily into the entryway because of the borehole drilling when creating holes, and the local flooding of gas is extremely dangerous for the safety of miners.

Therefore, there are two main problems that need to be investigated when implementing CECGWEP in deep soft coal mines, namely, the technologies for supporting surrounding rock in the retained entryway, and for extracting gas safely. Different measures concerning CECGWEP need to be considered for the different geological conditions.

\section{Implementation of CECGWEP}

According to the degree of deformation of the surrounding rock, Table 1 and Fig. 3 divides CECGWEP into three measures based on the difficulties in controlling the surrounding rock.
Table 1 Implementation methods and applications of CECGWEP

\begin{tabular}{ll}
\hline $\begin{array}{l}\text { Sectional convergence rate } \\
\text { of entryway }(\%)\end{array}$ & Implementation methods \\
\hline$<30$ & $\begin{array}{l}\text { Roadway retention and face-lagging } \\
\text { inclined borehole } \\
\text { Roadway retention and face-advancing } \\
\text { inclined borehole } \\
\text { Roadway retention and high return } \\
\text { airway inclined borehole }\end{array}$ \\
$>50$ & \\
\hline
\end{tabular}

\subsection{Roadway retention and face-lagging inclined boreholes}

This technique is schematically illustrated in Fig. 3a. It is capable of the convergence rate of entry under $30 \%$ which can fulfill the requirements of space to let workers drill boreholes in retained entry. The geological conditions are simple and mining depth is small usually in this circumstance.

Since the stress has been redistributed after mining in the roof and floor of gob area, the stress concentration and rock mass rotation/subsidence of the face-lagging borehole are decreased, and then the stress environment of boreholes is also located in a relatively mitigated zone. Therefore, the borehole can be avoided sine potential breakage or cutting off and its stability can be maintained for a long time to guarantee the long-term drainage of gas. Total gas drainage and utilization rate of single hole also can be augmented.

\subsection{Roadway retention and face-advancing inclined borehole}

This technique is displayed in Fig. 3b. Compared with Fig. 3a, it can be seen that the boreholes are arranged in the advancing area of the face. The distance to the face can range from 60 to $80 \mathrm{~m}$. To accommodate the in situ stress in the strata, it is recommended that high strength casing should be adopted.

The boreholes are then reamed to release the pressure and a flexible backfilling method is used to perform a comprehensive controlling technique. These measures are aimed at guaranteeing the stability of the boreholes during the whole procedure of coal mining, regardless of advancing or lagging the face. The merits of this measure are that it can intercept the relieved gas in advance and effectively drain it away before it enters the face area, eliminating the danger of gas flooding from its source. This can create "one borehole for the three stages", which can be used simultaneously before, during and after the mining which extends the drainage duration of the borehole. However, the drilling location in advance of the face is unaffected by the mining during the drilling of boreholes. 


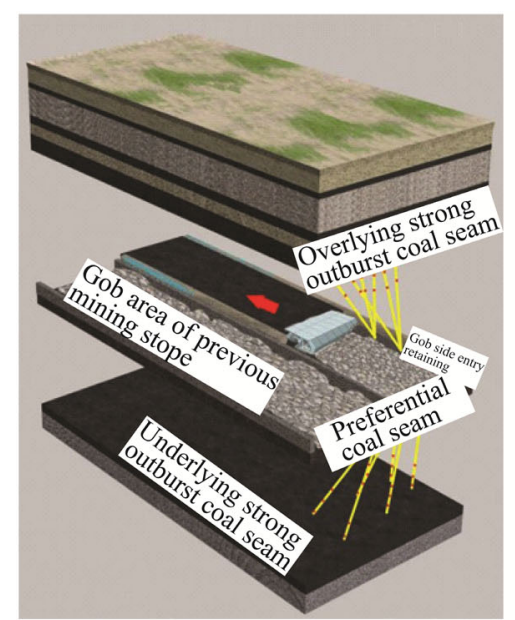

(a) With face-lagging inclined boreholes

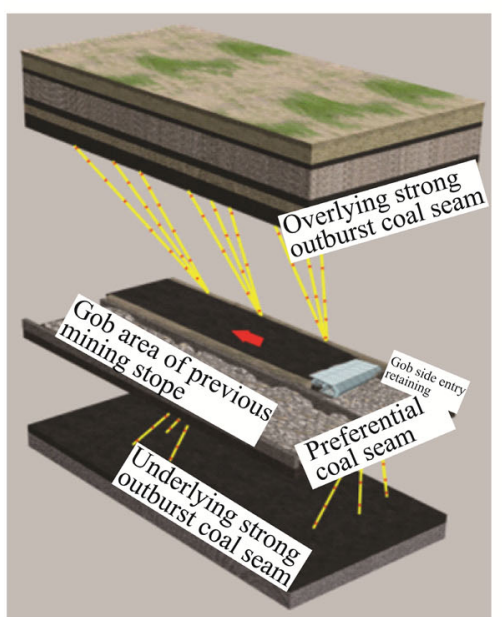

(b) With face-advancing inclined boreholes

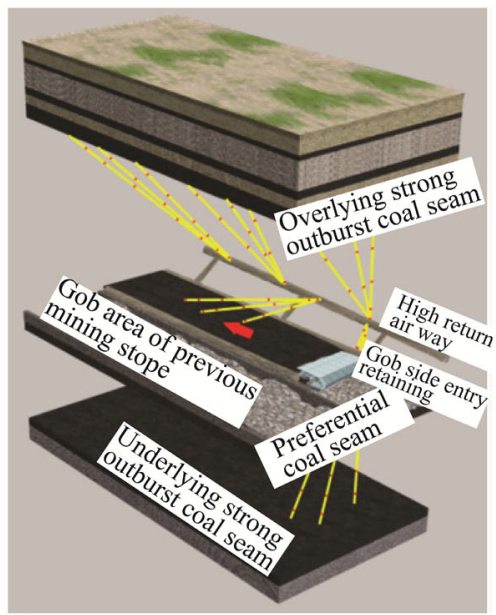

(c) With high return airway inclined boreholes

Fig. 3 Illustration of roadway retention of the three methods of implementing CECGWEP

Hence, drilling is easy to conduct. It decreases the requirements on the sectional area for drilling boreholes and plays an active role in controlling the surrounding rock mass. Because the entryway is little affected when the face is far enough from the drilling position, the rock mass is relatively intact, resulting in a high ratio of successfully drilled boreholes. Time can be saved for installing casing and for grouting or sealing the holes. Embedded gas will not be released in the areas in advance of the face, therefore making a large amount of gas emission during the drilling process impossible. The working conditions are safer than those illustrated in Fig. 3a.

\subsection{Roadway retention and high return airway inclined boreholes}

Retaining the gob-side entryway is characterized by continuous deformation. So short segment retention of the entryway is recommended when it is difficult to retain the whole entryway. This involves arranging an upper entryway above the original tailgate. These are connected by the return air crosscuts, as illustrated in Fig. 3c. Crosscuts are arranged at certain distances from each other in the direction of mining. The upper tailgate acts as drainage entry and a Y-type ventilation system can be created based on a combination of the upper drainage entryway, the original return air entryway, and the related crosscuts. The upper drainage entryway is barely influenced by the mining activity, which makes it possible to transfer the drilling work, initially assigned in the return air entryway, into the upper drainage entryway. With this approach, interference between the mining activity and drilling work can be avoided, thus providing adequate working space. In addition, boreholes drilled from the upper tailgate are far from the influence of mining activity taking place at the working face below. The maintenance cost of drainage boreholes can be significantly reduced compared with boreholes drilled ahead of the retained entryway or in the retained entryway (Liu et al. 2014). Additionally, boreholes beneath the current coal seam can also be drilled in the upper tailgate which avoids the additional drilling work such as arranging buried pipes in the gob area of the working coal seam or striking boreholes along the roof for gas drainage.

\section{Key technologies of CECGWEP in deep mines}

\subsection{Pressure relief in strata using presplitting blasts}

A presplitting blast is aimed at relieving the pressure in the rock mass that surrounds the retained entryway and is performed by blasting in deep drilled boreholes. This technique is appropriate for faces with thick and stiff roofs or where the immediate roof is too thin to accommodate the rotation and subsidence of the main roof. It consists mainly of two methods, the first is advanced deep-hole 


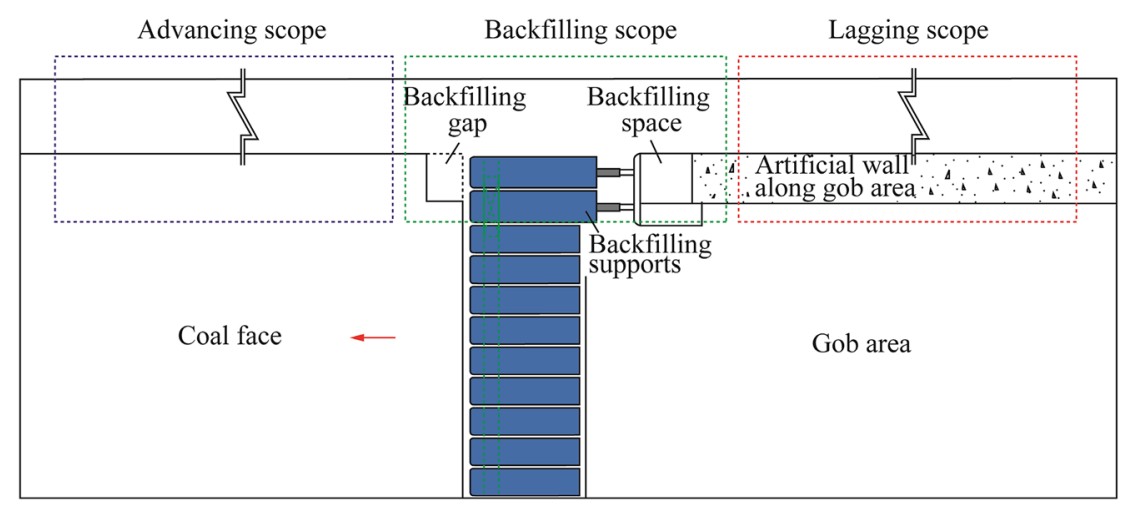

Fig. 4 Segments dividing gob-side entry retention

blasting for the caving roof along the inclination of the face, which can reduce the distance from the weight of the roof and reduce the concentration of the weight. The second advances the group of blasting holes along the strike direction of the face. They are horizontally distributed with small rotational angles from each other which eliminate the lateral roof cantilever located above the retained entryway. The regional structure of the roof can be adjusted accordingly and the stress field surrounding it can also be optimized. The layout form and parameters of blasting holes need to be optimized for the specific geological conditions.

\subsection{Divisional control technology on surrounding rock in retained entryways}

On the basis of the characteristics of the deformation and the distribution of the pressure on the abutment in the retained gob-side entryway, the procedure for retaining the entryway can be divided into advanced, backfilled, and lagging scopes, as schematically plotted in Fig. 4. Mining induced pressure will show different characteristics in different scopes, so their space-time conditions also vary with respect to each other. Therefore, different strategies need to be adopted. Maintenance measures in the advanced segment consist of secondary strengthening supports, advanced supports, and presplitting blasts to perform pressure relief. Maintenance measures in the backfilled segment consist of roof reinforcement in the scheduled backfilled area, and the construction of a backfilling wall along the gob side. Maintenance in the lagging segment contains auxiliary supports in the retained entryway, regional reinforcement, and related maintenance on the backfilling wall.

A certain amount of deformation should be designed to guarantee the normal sectional area of the retained entryway. However, the increased width of the entryway will increase the difficulties in controlling the roof and coal ribs. To solve this problem, the optimal ratio of widthheight of the entryway is proposed to guarantee its safety, as demonstrated by Eq. (1). The width of the backfilling wall also influences the stability and cost of the whole system for retaining the entryway where the mining height is defined. To eliminate as far as possible the extra cost of retaining the entryway, and to ensure its technical feasibility, an optimal ratio of the width-height of the backfilling wall is suggested. Based on the appropriate value of this ratio, the backfilling wall can support the roof strata at the entrance, and also accommodate the deformation and rotation of upper strata in the future. The minimum value of the ratio that can withstand the roof and floor deformation is specifically expressed in Eq. (2)

$\frac{1}{2} \leq \frac{b}{h} \leq \frac{1}{h}\left\{\frac{\left[R_{\mathrm{m}}\left(\frac{m_{0}}{E}+\frac{h_{1}}{E_{1}}+\frac{h_{2}}{E_{2}}\right)+\delta\right] l}{m_{0}-(K-1) h_{1}}-x_{0}\right\}$

$\frac{\left(b+x_{0}\right) \eta \gamma m}{h\left(\sigma_{1}-\eta \gamma m\right)} \leq \frac{a}{h} \leq \frac{\left[R_{\mathrm{b}}\left(\frac{m}{E}+\frac{h_{1}}{E_{1}}+\frac{h_{2}}{E_{2}}\right)+\delta\right] l}{h\left[m-(K-1) h_{1}\right]}-\frac{\left(x_{0}+b\right)}{h}$

where $b$ and $h$ are the width and height of the entryway; $R_{m}$ is the minimum strength of the roof and floor in the entryway; $m$ the mining height; $h_{1}$, and $h_{2}$ the thickness of the immediate roof and floor; $E, E_{1}$, and $E_{2}$ the elasticity modulus of the backfilling wall, immediate roof, and immediate floor, respectively; $\delta$ the hanging roof behind the face; $l$ the length of the key block; $K$ the bulking coefficient of the immediate roof; $x_{0}$ the horizontal distance from the fracture point of main roof to the workface of the gob-side entryway; and $\eta$ is a constant ranging from 4 to 8 .

\section{3 "The trinity" surrounding rock controlling techniques in retained entryways}

The basis of supporting the retained entryway is to initially apply bolt support technology capable of adapting to the mining induced influences with the characteristics of "three highs" (high strength, rigidity, and pretension) to counteract shear failure. This can create high strength and 
high resistance stability in the surrounding rock bearing structure that can more effectively control the deformation of the surrounding rock of the roadway (Zheng et al. 2014). Auxiliary reinforcement uses auto shift roof supports, which mutually control the roof and floor. Accompanied by the high strength wall of roadside filling, this forms the total structure of "the trinity" supporting system, effectively controlling the deformation of the surroundings of the retained entryway.

\subsection{Regional control technology for borehole maintenance}

The deformation of the roof strata varies in different areas and the strata stress will redistribute itself. Thus, the form of damage to borehole casings in different areas is diverse. As shown in Fig. 5, the axial length, according to the broken line and the drilling strata after pressure relief, can be divided into three regions: the compression failure zone, the compression-shear transition zone, and the shear failure zone. The damage characteristics of different zones need different measures for borehole maintenance. In the compressive failure zone, the borehole casing should be thickened to resist the compressive stress, while in the shear failure zone, the key shear strata should be reamed to increase the diameter of the borehole.

The speed of building the backfilling wall should match the advancing speed of the fully mechanized working face. Therefore, a technique for fast building of the backfilling wall was developed. Bagged backfill material is transported to the workplace by a mine car; a vacuum chuck transports the material to an automatic unpacking machine; a throughthe-pipe belt conveyor then sends the material to a blender and mixed with water; a backfill pump sends the material for backfilling to behind the formwork supporting the roof. The backfilling wall is ready after curing and removing the formwork. The speed of backfilling can reach $10 \mathrm{~m}$ per day. By optimizing the ratio of the materials, the final strength of the backfilling wall achieves at least $30 \mathrm{MPa}$.

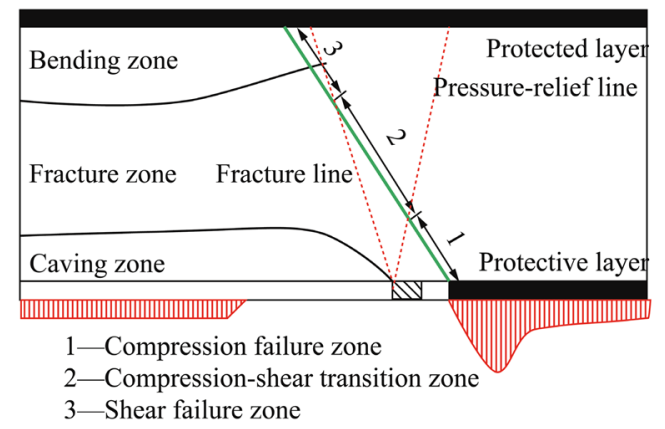

Fig. 5 Distribution of damage in the roof strata
This strength can satisfy the basic requirements for the retained entryways in thousand-meter-deep coal mines.

\subsection{Rapid casing installation and borehole sealing technology}

To ensure the stability of a borehole in the extraction process, the casing is installed after the borehole is created. However, metal casing is heavy and difficult to install manually. Therefore, in designing the casing, the casing connector should match the drill pipe. With the appropriate assistance of the drilling machine, the construction quality and efficiency of the installation of the casing can be improved.

The borehole sealing quality decides whether the air will escape through the borehole from the casing and fracture zones, which will reduce the gas concentration of extraction, and also influence the stability of the borehole. Therefore, the technology of injection sealing was developed. Both sides of the borehole (beginning and end segments) are sealed using the high polymer material, Marithan, which has an excellent adhesion, expansion and sealing performance, to achieve rapid sealing of the borehole. High strength and zero shrinkage cement material is injected into the sealed boreholes. This slurry is composed of cement and additives with a cement ratio as high as a 1/4. The compressive strength can reach $70 \mathrm{MPa}$ and enhance the compressive properties of the materials compared with traditional cement. At the same time it can improve the sealing performance of drilled boreholes.

\section{Engineering implementation}

\subsection{Roadway retention and face-lagging inclined borehole}

Yuan (2008) introduced this technique in detail and it was proved to be effective and efficient in CECGWEP by field test. The study is not repeated here.

\subsection{Roadway retention and face-advancing inclined borehole}

\subsubsection{Engineering and geological conditions}

The trial area was located in panel 1111(1) of the Zhuji Coal Mine, operated by the Huainan Mining Group, China. The face elevation was -877.6 to $-907.0 \mathrm{~m}$. As shown in Fig. 6, the panel was $1608 \mathrm{~m}$ long and $220 \mathrm{~m}$ wide. It had an average thickness of $1.26 \mathrm{~m}$ and an average dip angle of $3^{\circ}$, ranging from $1^{\circ}$ to $5^{\circ}$. The $\mathrm{CH}_{4}$ content was $4.73-5.15 \mathrm{~m}^{3} / \mathrm{t}$. The face was mined using retreating long- 


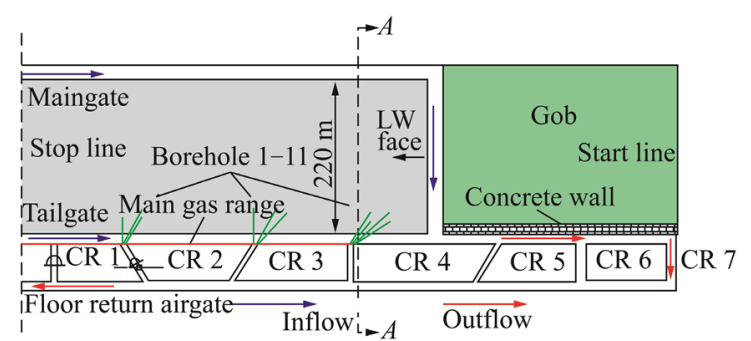

Fig. 6 Plan view of panel 1111(1)

wall mining. The working seam was overlain by Seam 13-1, which was outburst-prone coal with gas content of $6.98 \mathrm{~m}^{3} / \mathrm{t}$, at a distance of $65 \mathrm{~m}$. There were seven connection roadways $(\mathrm{CR}) 1-7$ from the starting line to the finishing line between the tailgate and the floor return airgate (Fig. 6).

\subsubsection{Roadway retention surrounding rock control parameters}

(a) Initial support: The roof bolt was designed as seven non-longitudinal-ribs rebar bolts at intervals of $750 \mathrm{~mm} \times 800 \mathrm{~mm}$. The diameter and length of the bolt were 22 and $2800 \mathrm{~mm}$. The yield strength of the bolt was $400 \mathrm{MPa}$. The roof cable chosen was a cable-beam with four holes. The beam was made from No.20 channel steel and the cable was made from high strength and low relaxation steel fiber, with a diameter of $21.8 \mathrm{~mm}$ and yield strength of $1860 \mathrm{MPa}$. The interval between the cable-beams was $800 \mathrm{~mm}$. The rib bolt used full screw and identity intensity bolts, with intervals of $650 \mathrm{~mm} \times$ $800 \mathrm{~mm}$. The bolt diameter was $20 \mathrm{~mm}$ and its length $2500 \mathrm{~mm}$. There were five anchors on each rib wall. The roof and two sidewalls all adopted No.8 barbed wire and M-steel belts.

(b) Advanced reinforcement: The roof was strengthened using two cables, whose specifications were the same as the upper roof. The sidewall of the nonmining area was strengthened by two rows of horizontal cable-beams. The beam was made of No.11 joist steel and the cable length was $4300 \mathrm{~mm}$.

(c) Auxiliary support: DZ35-42 single props, four meters No.11 joist steel and a $1.2 \mathrm{~m}$ long articulated top beam were used to provide auxiliary strength to the support up to $60 \mathrm{~m}$ from the advanced working face.

\subsubsection{Test borehole layout parameters}

As shown in Fig. 6, a total of 11 inclined cross-measure drainage boreholes in three successive groups were drilled at CR 4, CR 3, and CR 2. They were separated from the start line by 840,1180 , and $1460 \mathrm{~m}$. To ensure the stability and reliability of the boreholes, a variety of casings were used to protect them. In the first group of boreholes, $\phi$ $89 \times 6.45 \mathrm{~mm}$ geological drill rod was used as the protective casing. In the second group, a dual combined casing $(\phi 89 \times 6.45 \mathrm{~mm}$ geological drill rod inner and $\phi$ $139.7 \times 9.17 \mathrm{~mm}$ oil casing outer) was used. In the third group, $\phi 89 \times 13 \times 1500 \mathrm{~mm}$ and $\phi 177.8 \times 19 \times$ $1500 \mathrm{~mm}$ special thick-wall oil casing and the double-layer casing were used.

\subsubsection{Effect of roadway retention and extraction}

The length of successful roadway retention reached $1608 \mathrm{~m}$. In the whole process of roadway excavation for its reuse, the deformation of the sidewall, roof, floor and backfill wall were 760, 235, 1215 and $50 \mathrm{~mm}$, respectively. When the lagging length from the working face reached $80-100 \mathrm{~m}$, the roadway achieved stability. The sectional area of the roadway was approximately $4-5 \mathrm{~m}^{2}$. The actual appearance is shown in Fig. 7.

The methane flow rates for the face-advancing inclined boreholes of panel 1111(1) are shown in Fig. 8. The maximum methane flow of the extraction borehole reached $4.9 \mathrm{~m}^{3} / \mathrm{min}$ and the average methane flow reached $1.9 \mathrm{~m}^{3} /$ $\min$. The effective extraction length was more than $150 \mathrm{~m}$. It met the needs of working face of gas extraction.

\subsection{Roadway retention and the high return airway inclined borehole}

\subsubsection{Engineering and geological conditions}

As highlighted in Fig. 9, the average mining depth of panel 1112 (1) in the Zhuji Mine was $960 \mathrm{~m}$. The mining height was $1.8 \mathrm{~m}$, the $\mathrm{CH}_{4}$ content $4.73-5.15 \mathrm{~m}^{3} / \mathrm{t}$, the ground temperature $36.5-45{ }^{\circ} \mathrm{C}$, the panel length $2059 \mathrm{~m}$ and the thickness of the working coal seam $1.37 \mathrm{~m}$. The roof of the seam was made up of, from the bottom up, $4.8 \mathrm{~m}$ thick mudstone, a $0.2 \mathrm{~m}$ thick coal streak and $4.2 \mathrm{~m}$ thick fine sandstone. The floor of the seam was made up of, from the top down, $4.5 \mathrm{~m}$ thick mudstone, a $0.8 \mathrm{~m}$ thick coal seam and $3.2 \mathrm{~m}$ thick mudstone.

\subsubsection{Roadway retention surrounding rock control parameters}

(a) Initial support: The roadway cross section was $5 \mathrm{~m} \times 3 \mathrm{~m}$. The "three highs" bolt and cable-beam were used for the active support. The roof bolts were sinistral non-longitudinal-rib high strength bolts. The 


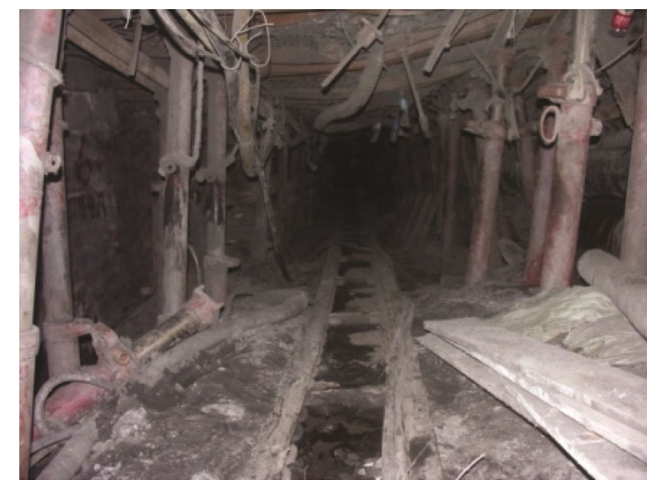

Fig. 7 The appearance of panel 1111(1) roadway retention

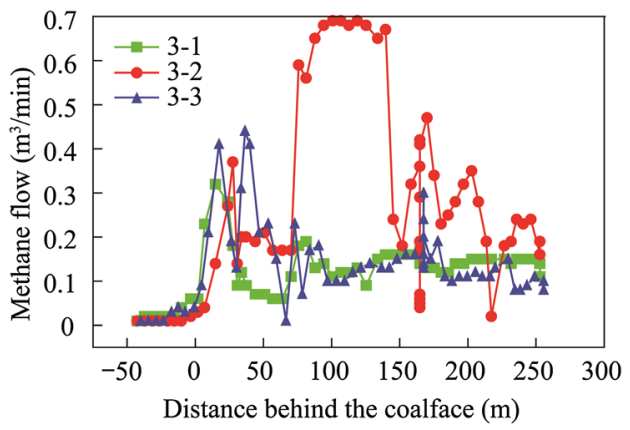

Fig. 8 Methane flow curve of the face-advancing inclined boreholes

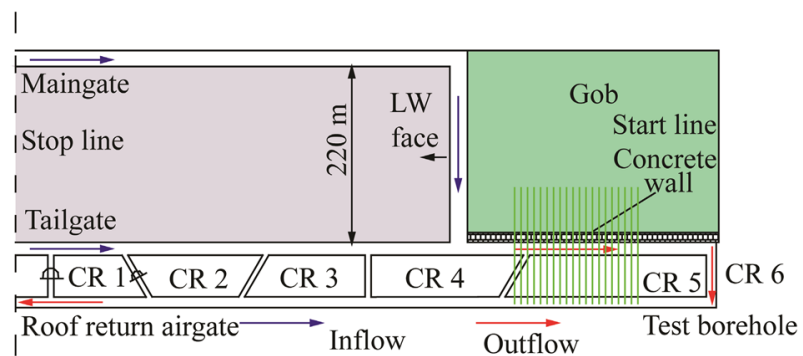

Fig. 9 Plan view of panel 1112(1)

sidewall bolts were dextrorotatory full-thread bolts at intervals of $700 \mathrm{~mm} \times 800 \mathrm{~mm}$.

(b) Advanced reinforcement: The cable-beam and grouting reinforcement had to be carried out ahead of the working face by at least $200 \mathrm{~m}$. The method meant that the original roadway roof was reinforced by cable-beams, while two cable-beams were installed on the non-mining sidewall $650 \mathrm{~mm}$ from the roof and floor by the alternate application of single-beam hollow grouting cables and common cables. The installation angle of the upper cable was $30^{\circ}$ upward, while it was downward for the lower cable. At the same time, at the advancing working face and the mining sidewall of the retained roadway, the coal section of $1.7 \mathrm{~m} \times 3.5 \mathrm{~m}$ was broken manually for the bolt system reinforcing, and an articulated beam was installed as auxiliary support.

(c) Auxiliary support: DZ35-42 single props, $4 \mathrm{~m}$ No.11 joist steel and a $1.2 \mathrm{~m}$ long articulated top beam were used to provide auxiliary strength to the support up to $50 \mathrm{~m}$ from the advanced working face.

\subsubsection{Test borehole layout parameters}

The location of the installation of the boreholes was changed to a high return airway from the retained roadway along the advancing direction of the working face. The borehole spacing was $10 \mathrm{~m}$ with an inclination angle of $30^{\circ}$ and a borehole length of $80 \mathrm{~m}$. A $\phi 91 \times 4.5 \mathrm{~mm}$ core barrel was installed in each borehole for protection.

\subsubsection{Roadway retention and extraction effect}

The successfully retained roadway reached $2059 \mathrm{~m}$. In the whole process of reusing the roadway excavation material, the deformation of the sidewall, roof, floor and wall was $110-450,257-450,1311-2500$ and $61-90 \mathrm{~mm}$, respectively. Within the lagging length of $300 \mathrm{~m}$ from the working face, the width remained $4.4-4.9 \mathrm{~m}$, and the height exceeded $1.5 \mathrm{~m}$. The actual appearance is shown in Fig. 10. The sectional area of ventilation also exceeded $6.5 \mathrm{~m}^{2}$ and satisfied the needs of the working face.

The methane flow rates of the high return airway inclined boreholes of panel 1112(1) are shown in Fig. 11. Because the borehole was far from the mining-induced area, the strength and thickness of the core barrel installed in the high return airway inclined boreholes were lower than that of the face-advancing inclined boreholes. The cost of borehole protection dropped sharply, and the extraction of gas was guaranteed. The maximum methane extraction flow of a single borehole reached $8.1 \mathrm{~m}^{3} / \mathrm{min}$,

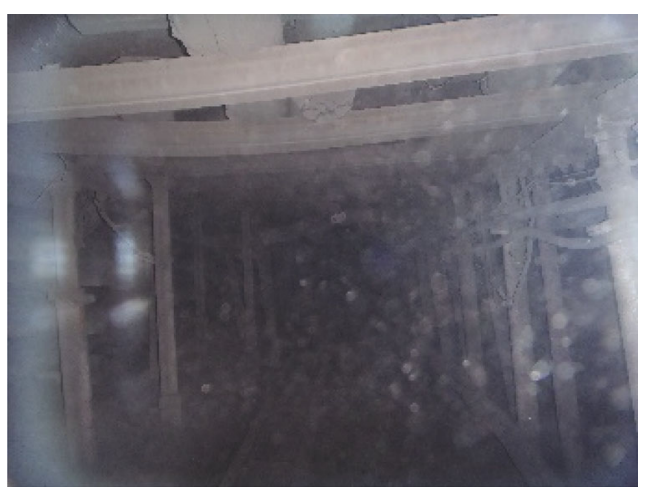

Fig. 10 The appearance of the working face 1112(1) roadway retention 


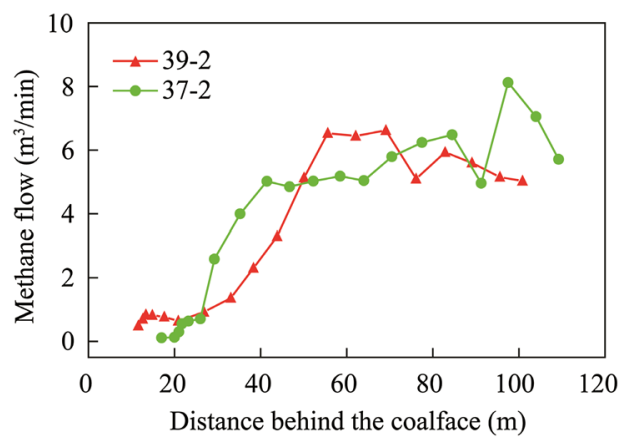

Fig. 11 Methane flow curve of the high return airway inclined boreholes

and the effective extraction reached more than $100 \mathrm{~m}$. The required volumes of working face gas extraction were met.

\section{Conclusions}

(1) Three measures for the co-extraction of coal and gas without an entry pillar (CECGWEP) were introduced. They were roadway retention and face-lagging inclined boreholes, roadway retention and faceadvancing inclined boreholes, and roadway retention and high return airway inclined boreholes.

(2) Several essential techniques were put forward to improve the maintenance effects for retained entryways and to stabilize the boreholes which provide pressure relief in the strata. These used presplitting blasts, divisional control technology on surrounding rock in the retained entryways, "the trinity" surrounding rock controlling technique in retained entryways, regional control technology of borehole maintenance and rapid casing installation and borehole sealing technology.

(3) The faces 1111(1) and 11112(1) in the Zhuji Mine were considered for the latter two measures. According to the results, the CECGWEP technology can effectively solve the problems in deep mines. The maximum gas drainage flow of a single hole can reach $8.1 \mathrm{~m}^{3} / \mathrm{min}$, and the effective drainage distance can be extended up to $150 \mathrm{~m}$ or more.

Acknowledgments The research was supported by Program for Changjiang Scholars and Innovative Research Team in University (IRT_14R55), and the National Natural Science Foundation of China under Grant No. NSFC-51274193.

Open Access This article is distributed under the terms of the Creative Commons Attribution 4.0 International License (http:// creativecommons.org/licenses/by/4.0/), which permits unrestricted use, distribution, and reproduction in any medium, provided you give appropriate credit to the original author(s) and the source, provide a link to the Creative Commons license, and indicate if changes were made.

\section{References}

Bibler CJ, Marshall JS, Pilcher RC (1998) Status of worldwide coal mine methane emissions and use. Int J Coal Geol 35:283-310

Kang H, Niu D, Zhang Z, Lin J, Li Z, Fan M (2010) Deformation characteristics of surrounding rock and supporting technology of gob-side entry retaining in deep coal mine. Chin J Rock Mech Eng 29:1977-1987

Karacan CO, Ruiz FA, Cote M, Phipps S (2011) Coal mine methane: a review of capture and utilization practices with benefits to mining safety and to greenhouse gas reduction. Int $\mathrm{J}$ Coal Geol $86: 121-156$

Keim SA, Luxbacher KD, Karmis M (2011) A numerical study on optimization of multilateral horizontal wellbore patterns for coalbed methane production in Southern Shanxi Province, China. Int J Coal Geol 86:306-317

Kong S, Cheng Y, Ren T, Liu H (2014) A sequential approach to control gas for the extraction of multi-gassy coal seams from traditional gas well drainage to mining-induced stress relief. Appl Energy 131:67-78

Li W, Cheng Y, Guo P, An F, Chen M (2014) The evolution of permeability and gas composition during remote protective longwall mining and stress-relief gas drainage: a case study of the underground Haishiwan Coal Mine. Geosci J 18:427-437

Liu C, Zhou F, Yang K, Xiao X, Liu Y (2014) Failure analysis of borehole liners in soft coal seam for gas drainage. Eng Fail Anal 42:274-283

Lu S, Cheng Y, Ma J, Zhang Y (2014) Application of in-seam directional drilling technology for gas drainage with benefits to gas outburst control and greenhouse gas reductions in Daning coal mine, China. Nat Hazards 73:1419-1437

Pan R, Cheng Y, Yuan L, Yu M, Dong J (2014) Effect of bedding structural diversity of coal on permeability evolution and gas disasters control with coal mining. Nat Hazards 73:531-546

Whittles DN, Lowndes IS, Kingman SW, Yates C, Jobling S (2007) The stability of methane capture boreholes around a long wall coal panel. Int J Coal Geol 71:313-328

Xia T, Zhou F, Liu J, Hu S, Liu Y (2014) A fully coupled coal deformation and compositional flow model for the control of the pre-mining coal seam gas extraction. Int $\mathrm{J}$ Rock Mech Min 72:138-148

Xie H, Zhou H, Xue D, Gao F (2014) Theory, technology and engineering of simultaneous exploitation of coal and gas in China. J China Coal Soc 39:1391-1397

Xue S, Yuan L, Wang Y, Xie J (2014) Numerical analyses of the major parameters affecting the initiation of outbursts of coal and gas. Rock Mech Rock Eng 47:1505-1510

Yang W, Lin B, Yan Q, Zhai C (2014) Stress redistribution of longwall mining stope and gas control of multi-layer coal seams. Int J Rock Mech Min 72:8-15

Yuan L (2008) The technique of coal mining and gas extraction by roadway retaining and borehole drilling. J China Coal Soc 33:898-902

Yuan L, Xue J, Zhang N, Lu P (2013) Development orientation and status of key technology for mine underground coal bed methane drainage as well as coal and gas simultaneous mining. Coal Sci Technol 9:6-11

Zhang N, Yuan L, Han C, Xue J, Kan J (2012) Stability and deformation of surrounding rock in pillarless gob-side entry retaining. Safety Sci 50:593-599 
Zhang NC, Esterle J, Zhang N et al (2013) Analysis on Wedge-shaped roof mechanical behaviours under a thick sandstone layer with different longwall mining speed. In: Proceedings of 3rd international workshop on mine hazards prevention and control, Brisbane, pp 369-375

Zhang N, Zhang NC, Han C, Qian D, Xue F (2014) Borehole stress monitoring analysis on advanced abutment pressureinduced by Longwall Mining. Arabian J Geosci 7:457-463
Zheng X, Feng X, Zhang N, Liu J, Zhang L (2013) Fissures evolution law and gas drainage characteristics of remote decompressed mining. Disaster Adv 6:164-176

Zheng X, Feng X, Zhang N, Gong L, Hua J (2014) Serial decoupling of bolts in coal mine roadway supports. Arabian J Geosci: 1-14

Zhou H, Yang Q, Cheng Y, Ge C, Chen J (2014) Methane drainage and utilization in coal mines with strong coal and gas outburst dangers: a case study in Luling mine, China. J Natural Gas Sci Eng 20:357-365 